\title{
Impact of government budget on health prepayment levels: evidence from OECD countries
}

\author{
Ying Zhang, Jacques Vanneste, ${ }^{2}$ Wenqing $\operatorname{Pan}^{3}$ and Liuyue Zhang
}

${ }^{1}$ Department of Finance, School of Economics and Management, Southeast University, Nanjing, China (Correspondence to: Y. Zhang: yingzhang@seu. edu.cn). ${ }^{2}$ Faculty of Business and Economics, University of Antwerp, Antwerp, Belgium. ${ }^{3}$ Department of International Finance, School of Economics, Fudan University, Shanghai, China.

\begin{abstract}
Background: Health prepayment, a key indicator under the Sustainable Development Goals monitoring framework, is strongly associated with household financial protection; however, the impact of government health budget on the level of prepayment has rarely been discussed.

Aims: To address the following research questions. (1) Does a higher government health budget translate into higher prepayment rates in the healthcare financing system? (2) What are the effects of government health budget on public prepayment and private prepaid plans? (3) What are the heterogeneities between groups of countries with different income levels and public health prepayment systems?

Methods: Analysis of panel co-integration, impulse response function, and variance decomposition were conducted in 34 Organisation for Economic Co-operation and Development (OECD) members for the period 1995-2016.

Results: Government health budget has a long-running equilibrium relationship with the level of public and total prepayment. However, a stable relationship could not be confirmed with private prepaid plans. Moreover, government health budget played a significant positive role in explaining the fluctuations in the total and public prepayments over a long time, that is, 51 and 37 periods, respectively. Considering differences between groups of countries, the impacts are greater for those with higher income levels and more public-dominated health-financing systems.
\end{abstract}

Conclusions: Government health budget has a long-time relationship with the levels of both total prepaid expenditure and public prepayment. By contrast, it does not systematically crowd out private prepaid plans.

Keywords: government health budget, healthcare financing, OECD, private prepaid plan, public prepayment

Citation: Zhang Y; Vanneste J; Pan W; Zhang L. Impact of government budget on health prepayment levels: evidence from OECD countries. East Mediterr Health J. 2021;27(1):41-49. https://doi.org/10.26719/emhj.20.108

Received: 20/06/19; accepted: 02/01/20

Copyright ( ) World Health Organization (WHO) 2021. Open Access. Some rights reserved. This work is available under the CC BY-NC-SA 3.o IGO license (https://creativecommons.org/licenses/by-nc-sa/3.o/igo).

\section{Introduction}

Globally, health care remains important but expensive. Good health and well-being is the third of 17 global Sustainable Development Goals launched by the United Nations in 2015 with approximately $10.0 \%$ of global gross domestic product (GDP) dedicated to health that year. Between 2000 and 2015, average annual real growth rate of the global health economy was $4.0 \%$ compared with $2.8 \%$ for the overall global economy (1). Health accounts for a large proportion of the GDP and government budget of the world's top 10 economies (Figure 1).

Prepayment of healthcare financing ${ }^{1}$ is crucial to ensure that all individuals have access to effective public and personal healthcare at affordable prices. A high level of prepayment, especially through public financing via a tax-based system, social health insurance scheme, or mixed system, positively affects the fairness of the payment distribution burden. Additionally, public financing spreads financial risks more strategically and subsidises poorer people. The degree of risk sharing in a health financing organization positively affects its health system attainment (2). In contrast, healthcare financing systems with high out-of-pocket (OOP) payments create problems of access, particularly for vulnerable groups including low-income populations.

Considerable research has examined the determinants of prepayment levels in terms of both public prepayment and private prepaid plans (Appendix). For public prepayment, these factors include economic growth, Wagner's law, demographic heterogeneity, political legitimacy, and capitalism. In particular, the important stewardship role that the government can play may facilitate the transition to higher levels of prepayment even in slower-growing countries (3). The public prepaid financing system is an important tool for the ruling party to ease conflict among different social classes and maintain political power. To safeguard its legitimate status, the system can be improved as political opposition

According to the World Health Organization definition, prepayment refers to the health expenditure excluding out-of-pocket payments. Public prepayment includes transfers from government domestic revenue and social insurance contributions (from employers and employees). Private prepayment refers to the fund collected by private health insurance. 


\section{Figure 1 Large proportion of gross domestic product and budget expenditure on health for world's top 10 economies (2016)}

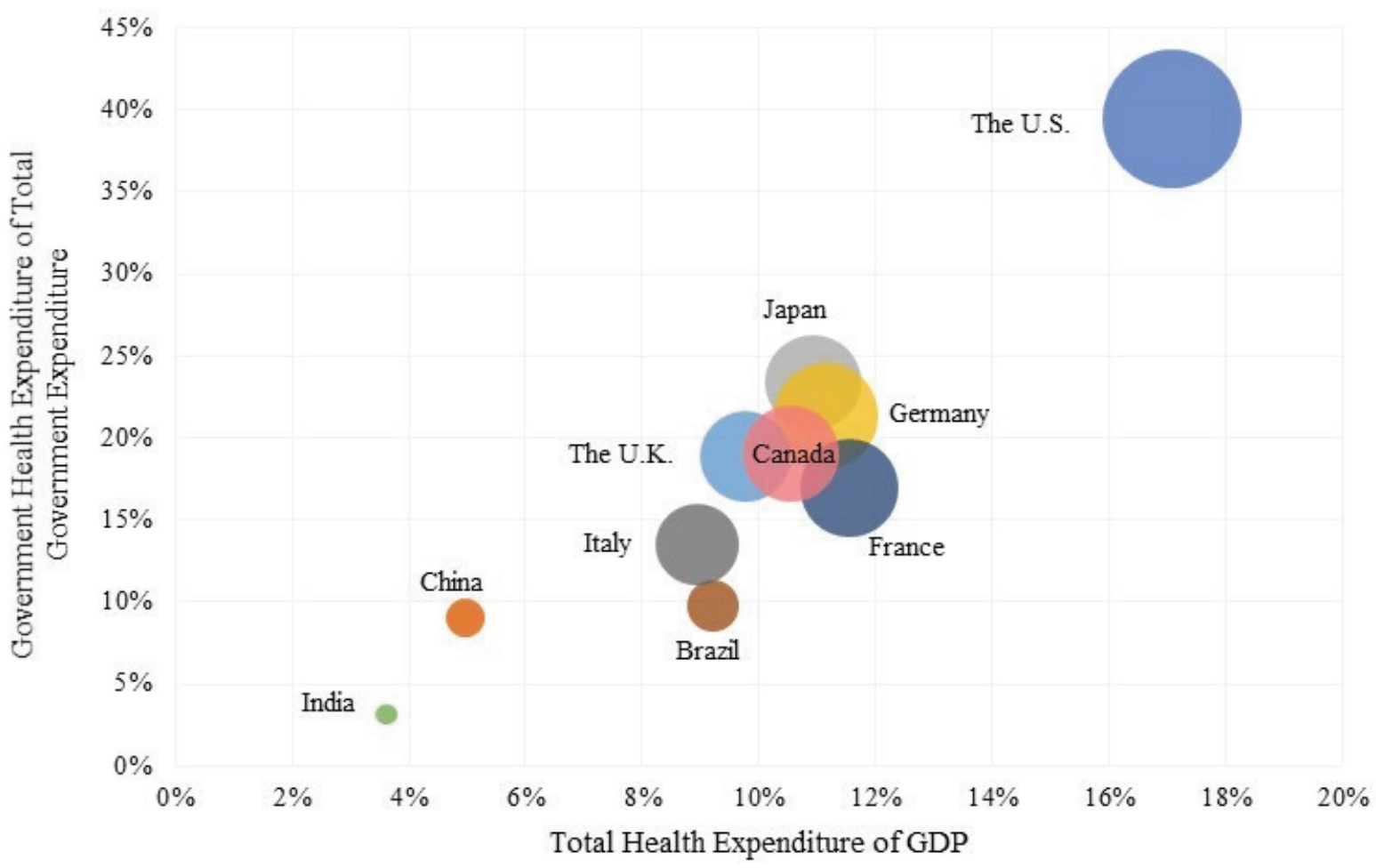

The size of each bubble represents the health expenditure per capita of the country. Ranking of national economies is provided by International Monetary Fund's World Economic Outlook for 2019. Since economies of different levels of development are compared, the health expenditure and out-of-pocket expenditure per capita is calculated in PPP int. \$ ( purchasing power of national currencies against USD).

Source: World Health Organization, 2019.

intensifies (4). For private prepayment, in addition to traditional socioeconomic and political demand factors including income (5-7), population ageing $(8,9)$, education levels $(10,11)$, and employment status (12), various other factors can explain the growth of private prepaid plans.
For instance, the longer waiting lists for National Health Service treatment in the United Kingdom of Great Britain and Northern Ireland have been associated with more purchases of private health insurance (PHI) (13). The service quality gap between public and private prepaid

\section{Table 1 Panel co-integration tests of prepayment, public and private financing}

\begin{tabular}{|c|c|c|c|}
\hline Methods & $\mathbf{Y}$ & $Y_{1}$ & $Y_{1}$ \\
\hline Pedroni (1999) Panel v-Stat. & $-0.251814(0.5994)$ & $1.220125(0.1112)$ & $-0.969307(0.8338)$ \\
\hline Pedroni (1999) Panel $\rho$-Stat. & $-3.082017(0.0010)$ & $-4.371516(0.0000)$ & $-0.385095(0.3501)$ \\
\hline Pedroni (1999) Panel pp-Stat. & $-3.546204(0.0002)$ & $-5.230357(0.0000)$ & $-0.891136(0.1864)$ \\
\hline Pedroni (1999) Panel ADF-Stat. & $-2.879510(0.0020)$ & $-4.653091(0.0000)$ & $-1.576539(0.0575)$ \\
\hline Pedroni (1999) Group $\rho$-Stat. & $-0.284915(0.3879)$ & $-0.934630(0.1750)$ & $3.359792(0.9996)$ \\
\hline Pedroni (1999) Group pp-Stat. & $-5.128860(0.0000)$ & $-5.939829(0.0000)$ & $0.205246(0.5813)$ \\
\hline Pedroni (1999) Group ADF-Stat. & $-4.828542(0.0000)$ & $-5.594431(0.0000)$ & $-0.817908(0.2067)$ \\
\hline Kao (1999) ADF t-Stat. & $-2.853071(0.0022)$ & $-5.389342(0.0000)$ & $-2.646904(0.0041)$ \\
\hline Johansen Fisher Fisher Stat. (from trace test) & $137.3(0.0000)$ & $134.5(0.0000)$ & $131.4(0.0000)$ \\
\hline $\begin{array}{l}\text { Johansen Fisher Fisher Stat. (from max-eigen } \\
\text { test) }\end{array}$ & $108.1(0.0014)$ & $104.7(0.0006)$ & $100.5(0.0014)$ \\
\hline
\end{tabular}

We report no intercept or trend results for Pedroni (1999) and Johansen Fisher tests. Panel $v$-Stat refers to panel variance statistic. Panel $\rho$-Stat refers to panel $\rho$ statistic. Panel pp-Stat refers to Panel Phillips-Perron (PP) statistic. Panel ADF-Stat refers to panel augmented Dickey-Fuller statistic. Group $\rho$-Stat refers to group $\rho$ statistic, a type of group mean panel cointegration statistics. Group pp-Stat refers to group Phillips-Perron statistic. Group ADF-Stat refers to group augmented Dickey-Fuller statistic. ADF t-Stat refers to augmented Dickey-Fuller t-Statistic based on cointegration test proposed by Kao (1999). Fisher Stat (from trace test) refers to trace statistics based on Johansen co-integration test. Fisher Stat (from max-eigen test) refers to maximum eigenvalue statistics based on Johansen co-integration test. 


\section{Figure 2 Effect of government health budget on the level of health prepayment}

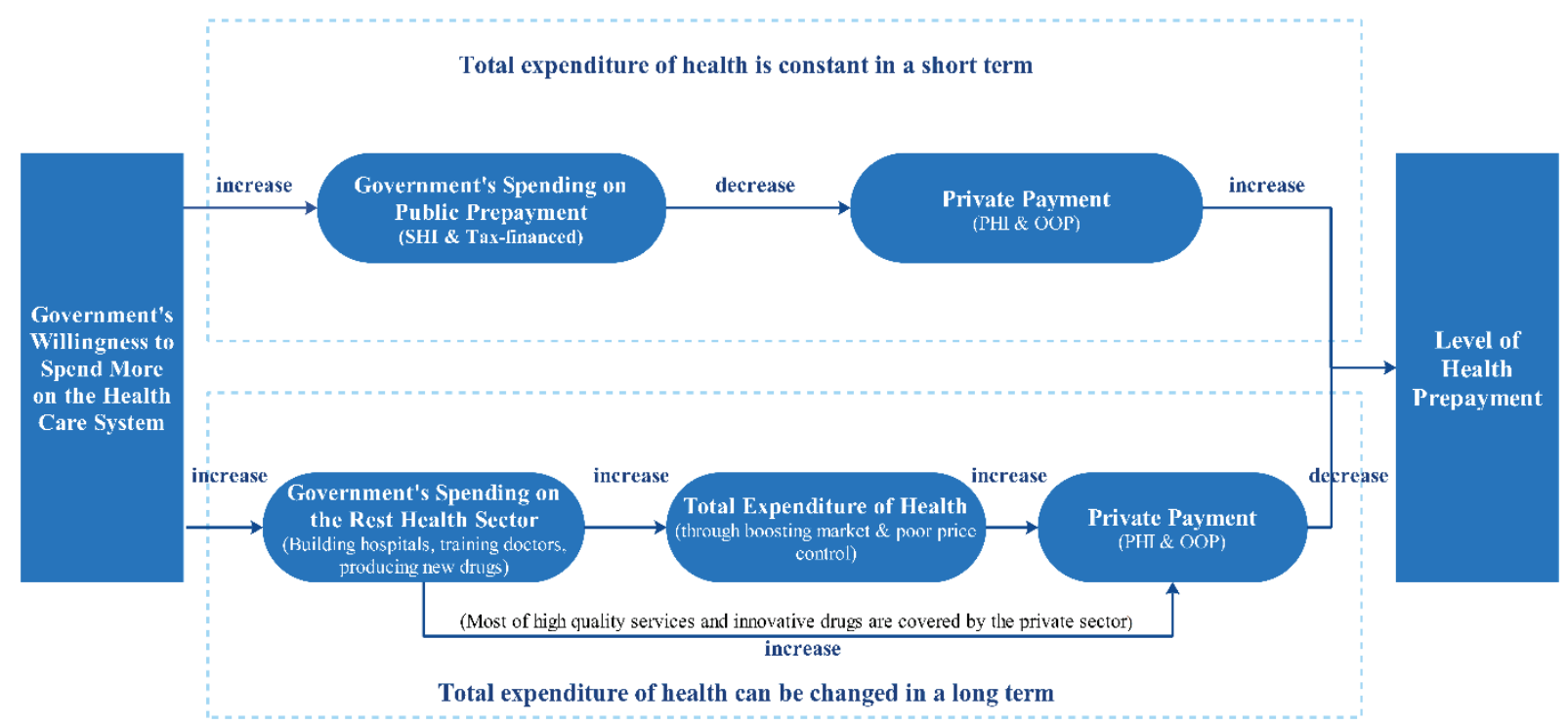

plans could also drive demand for PHI (14).

Government health budget influences prepayment levels through at least 2 channels (Figure 2). On the one hand, if the overall health expenditure remains constant in the short term, then when the government increases its expenditures in the health sector, the spending will partially go to the public prepaid system (social health insurance, tax-financed) and may cover a certain proportion of originally private spending, that is, private prepaid plans and OOP payments. Consequently, the level of prepayment increases (15). On the other hand, government spending on health may increase total expenditure in the health sector, thus driving longterm prepayment levels in the opposite direction (16). The increased government expenditure on health can also be used to build hospitals, train doctors and nurses, and produce innovative drugs, thus promoting the overall development of the health sector and boosting the market $(17,18)$. Compared with necessary medical services, high-tech equipment and services offered by well-educated employees are more expensive, while price regulation and control of premium healthcare packages are not always easy, particularly in a private-dominated system (19). Therefore, these conditions may boost total healthcare expenditure and private spending, including PHI and OOP costs. Hence, the prepayment level decreases simultaneously. Moreover, since public prepaid plans normally cover basic pharmaceutical services and drugs, most high-quality services and innovative drugs are paid for by private financing packages (e.g., private insurers and patients). Thus, these examples indicate that government budgetary increases in the health sector may have various impacts on public and private financing.

The aim of this study was to evaluate how such government health budgets operate in various economies.

\section{Methods}

\section{Empirical model}

To measure the long-term relationship between the level of healthcare prepayment and government health budget, we established a panel vector autoregressive (PVAR) model:

$$
\mathrm{Z}_{i t}=\mathrm{b} \mathrm{Z}_{i t-1}+\mathrm{a}_{i}+\mathrm{g}_{\mathrm{t}}+\mathrm{e}_{i t}(\mathrm{1})
$$

In Model (1), $Z_{\text {it }}$ is a vector of two variables ( $\left.Y, X\right)$. $Y$ denotes the prepaid expenditure on health (total health expenditure excluding OOP expenses) as a ratio to GDP. We divide healthcare prepayment into public prepayment $\left(Y_{1}\right)$ and private prepaid plans $\left(Y_{2}\right)$, with both expressed as a percentage of GDP. $X$ represents government expenditure on health as a share of total government expenditure, $\alpha_{i}$ represents the country-specific effects, $\gamma_{t}$ the time effects, $\beta$ the coefficient matrix, and $\varepsilon_{i t}$ the error term. The subscripts $i$ and $t$ denote country and year, respectively. This model includes only first-order lags, which are included based on the Bayesian information criterion.

In any dynamic model including lags of the dependent variables, inclusion of fixed effects creates biased coefficients because individual effects are correlated with the regressors. To mitigate this, our PVAR estimation routine follows the methods proposed by Love and Zicchino (20), using forward mean-differencing, also referred to as the Helmert procedure (21). Accordingly, all variables are transformed into deviations from forward means. This transformation preserves the orthogonality between transformed variables and lagged regressors, which allows us to use lagged regressors as instruments for the generalized method of moments estimation. The time effects are removed by subtracting the means of each variable calculated per country. 
Figure 3 Comparison of variables $\left(\mathrm{X}, \mathrm{Y}, \mathrm{Y}_{1}, \mathrm{Y}_{2}\right)$ among Organisation for Economic Co-operation and Development (OECD) members (1995-2016)

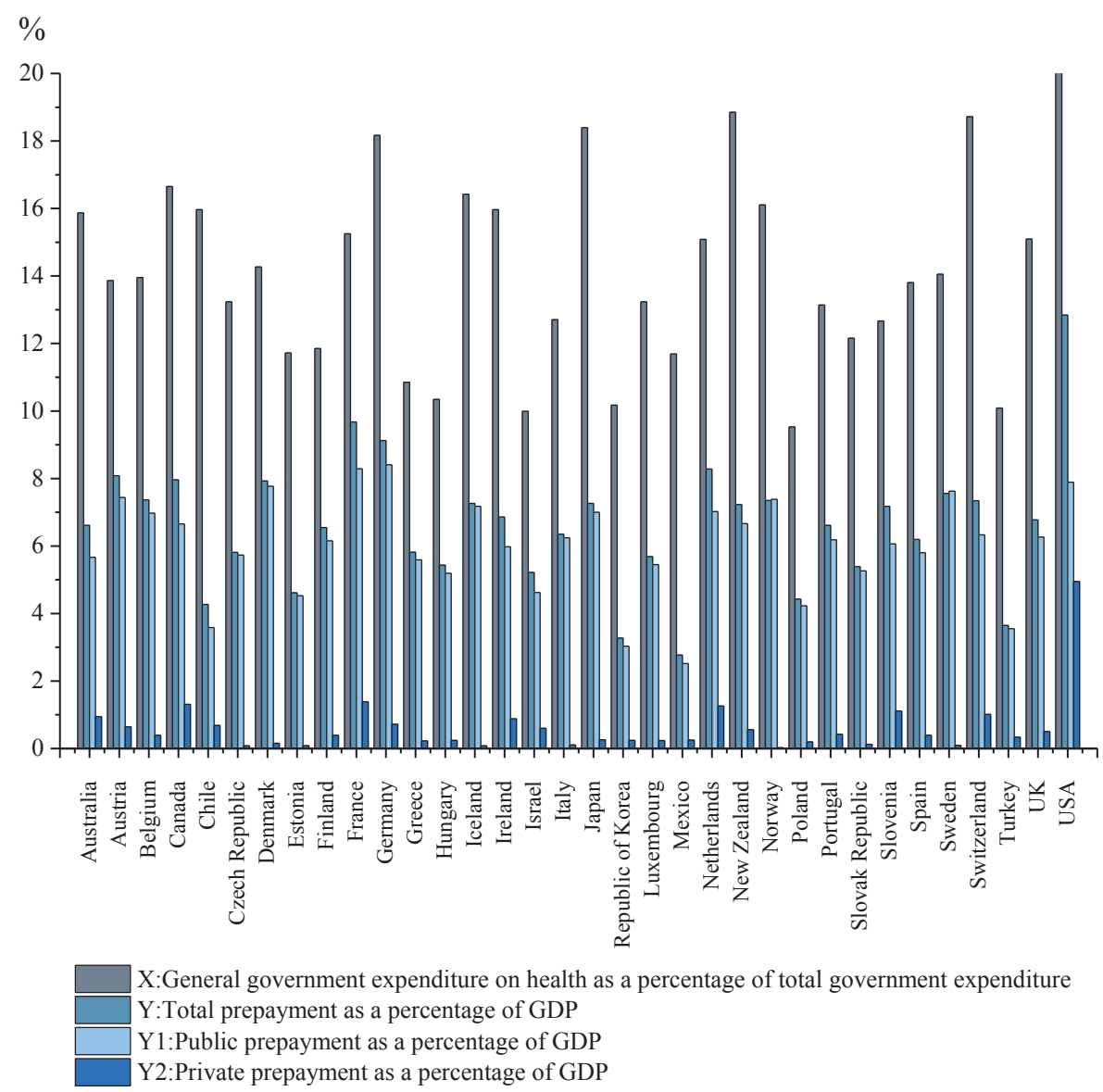

The PVAR methodology combines the traditional VAR approach, which treats all the variables in the system as endogenous, with the panel-data approach, which allows for unobserved individual heterogeneity (20). However, PVAR estimates are seldom interpreted by themselves. In practice, the impact of exogenous changes in each endogenous variable on other variables in the PVAR system is of interest. The prime benefit of this approach is evaluating the reaction of one variable to the innovations in another variable in the system, while holding all other shocks at o using impulse response functions (22). The impulse response function describes the evolution of the variable of interest along a specified time horizon after a shock in a given moment. Based on the equation of PVAR model, it captures the correlations between the present and future values of all endogenous variables because of its lagged specification. In this iterative process, any shock to 1 variable will have an effect on the values of other variables at the time of the shock and over subsequent periods. This feature allows one to trace the transmission of a single shock within a system and, thus, makes it a useful tool in the assessment of economic policies. Additionally, the PVAR system can measure the percentage variation in 1 variable that is explained by the shock to another variable accumulated over time, that is, variance decomposition.

Impulse response functions and forecast-error variance decompositions are conducted to investigate the dynamic effects of government's willingness to fund on the level of health prepayment. Accordingly, we can measure the impact of a shock in government's willingness to fund on the level of health prepayment and the percentage variance in health prepayment levels that are attributable to innovations in government's willingness to fund, respectively.

\section{Panel data}

We used the panel annual data of the 34 OECD member countries over the period 1995-2016, obtained mainly from the World Health Organization Global Health Observatory data and the OECD library. Figure 3 compares the variables among the countries. However, we excluded Norway, Sweden and Turkey because of missing values of private prepaid plans as a ratio of private health expenditure. Thus, we restricted our sample of the indicators $Y_{1}$ and $Y_{2}$ to 31 members. Additionally, the data series of $X$ was selected to match different panel data when analysing its relationship with $Y, Y_{1}$ and $Y_{2}$ separately. 


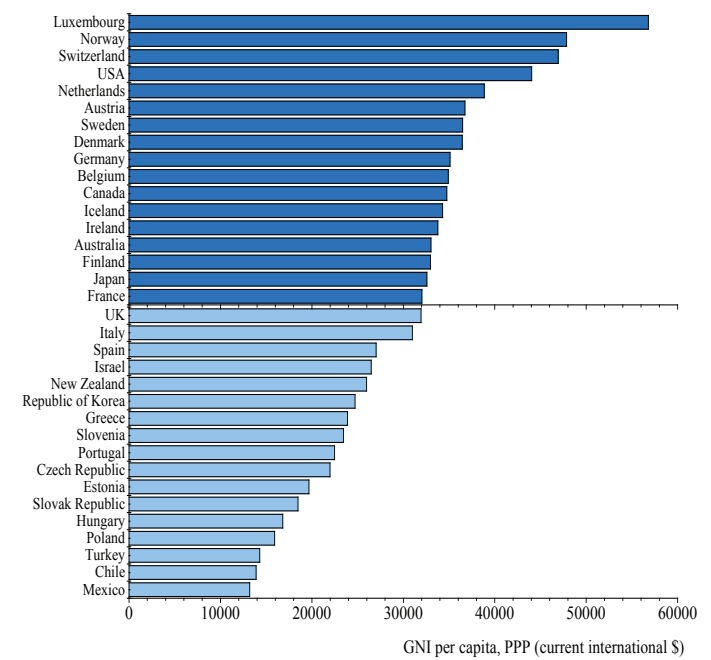

\section{Results}

\section{Overall effects}

\section{Panel cointegration analysis}

We first conducted unit root tests to examine whether the panel variables were stationary. Six best-known panel stationarity test methods were used, including the LLC (unit root tests for panel data proposed by Levin et al., 2002) (23), Breitung (24), IPS (unit root tests for panel data proposed by Im et al., 2003) (25), and 2 Fisher-type $(26,27)$ tests. The results showed that all the variables, $Y, Y_{1}, Y_{2}$ and $X$, were stationary after the first difference was taken, which simply means that the panel data variables were consistent with the AR(1) process (Appendix Table 2).

Subsequently, Pedroni (28), Kao (29) and Johansen Fisher panel cointegration tests were applied to examine whether long-term cointegration relationships existed between the level of health prepayment and a government's willingness to fund it, that is $(Y, X),\left(Y_{1}\right.$, $X)$, and $(Y, X)$. Table 1 indicates that the tests' results of indicators $(Y, X)$ and $(Y, X)$ rejected the null hypothesis of no cointegration at the $5 \%$ significance level. However, most of the test results for the indicators $\left(\mathrm{Y}_{2}, \mathrm{X}\right)$ did not reject the null hypothesis.

\section{Shock and fluctuation analysis by impulse responses and variance decompositions}

To investigate further the response of the level of health prepayment to the shock of government health budget, impulse response functions were constructed. Appendix Figure 1 illustrates the impulse responses of $Y$ in 34 countries and $Y$ and $Y_{2}$ in 31 countries to 1 standard deviation (SD) shock of $X$. Y positively responded to the shock of $X$, and this effect lasted for 51 periods. The impulse response of $Y$ expanded rapidly and peaked at 0.08 in the 1oth period before declining gradually until

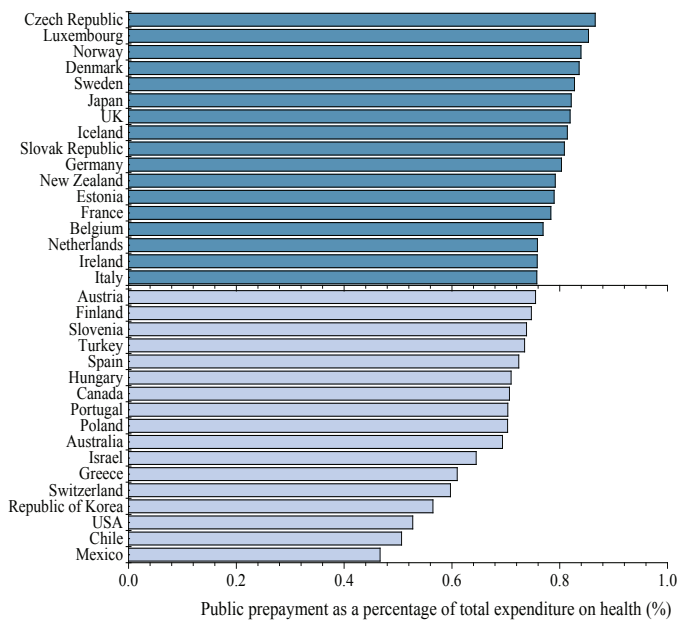

it approaches 0 in the 51st period. A similar pattern emerged in the impulse response of $Y_{1}$ to the shock of $X$, which increased dramatically to 0.016 in the 4th period before decreasing steadily to 0 in the 37th period. In contrast, the response curve of $Y_{2}$ immediately approachedo in the first several periods and remained flat thereafter. Appendix Table 5 shows that the percentages of variations in $Y$ and $Y_{1}$ explained by $X$ reached their peaks at $13.7 \%$ in the 51st period and $13.7 \%$ in the 37th period, respectively, while $X$ explained only at most $2.3 \%$ of the variation in $Y_{2}$ in the 96th period, which was lower than that of $Y$ and $Y_{1}$.

\section{Heterogeneity by country: income variance and prepayment variance}

To analyse whether heterogeneity by country mattered in the context of our study, we divided the 34 OECD members into groups by income levels and prepayment systems. Figure 4A represents the income differences among the members based on gross national income (GNI) per capita, while Figure $4 \mathrm{~B}$ represents the public prepayment differences using public prepayment as a percentage of total expenditure on health. The sample was divided by the medians of the 2 factors. First, through the average ranking of GNI per capita from 1995 to 2016 for the 34 countries, we identified the median income to be US\$ 31 974.09; Group A and Group B represented the panel above and below this median, respectively. The country with the highest GNI per capita was Luxembourg at US\$ 56800 and the lowest was Mexico at US\$13 197.27. Second, using the median of public prepayment as a percentage of total expenditure on health for the 34 countries, 17 countries (Group C) exceeded this median (i.e., $75.63 \%$ ) while the rest were classified in Group D. Among them, the Czech Republic had the highest (86.59\%) and Mexico the lowest (46.67\%) public dominance. 
As shown in Appendix Tables 3-6, the results of unit root tests and panel cointegration tests for subgroups were the same as those with the full sample panel. All the variables were first-order stationary. $(Y, X)$ and $(Y, X)$ were cointegrated but $\left(Y_{2}, X\right)$ were not.

The result of particular interest was the difference in impulse responses between subgroups. Appendix Figure 2 reports that a 1 SD shock in $X$ of Group B had shorter and weaker impacts on $Y$ than that of Group A (i.e., peaks at 0.004 , lasting for 27 periods compared with peaks at 0.023 , lasting for 48 periods). Similar features were found in $Y_{1}$ : Group A had greater response intensity and longer duration (i.e., peaks at 0.038 , lasting for 42 periods compared with peaks at 0.009 , lasting for 35 periods). By contrast, the responses of $Y_{2}$ to shock in $X$ were close to $\mathrm{o}$ for both Groups A and B. According to the results of variance decomposition, the proportions of variations in $Y$ and $Y_{1}$ attributed to $X$ were higher in Group A (Appendix Table 6).

Concerning the sample grouped by public dominance, the above patterns still existed. For instance, Appendix Figure 3 shows that the impulse response of $Y_{1}$ was stronger in Group C (i.e., peaks at 0.03 compared with 0.009). It is also worth noting that the percentage of variation in $Y_{1}$ that could be explained by the shock of $X$ in Group C was larger than in Group D (i.e., remained stable at $22.7 \%$ compared with $8.5 \%$ in the 33 rd period) (Appendix Table 7).

\section{Discussion}

For all OECD members, when a government highly prioritizes healthcare (i.e., the ratio of government expenditure on health to total government expenditure increases), the prepaid fund raised by social health insurance and/or tax increases greatly. Thus, the public prepayment level improves the total prepayment level simultaneously. Moreover, this effect is sustainable and persists in the short term because policies tend to have lagged effects. Compared to the positive effects, government health budgets have no effect on private prepaid plans, potentially because individuals purchase PHI according to their own health status, income level, and risk preferences, which are not directly affected by government health budgets.

The empirical results demonstrate that for countries with higher GNI per capita, the government health budget has greater and longer impacts on the public prepayment level. The income level of a country is related to its overall fiscal capacity and its government's decisions regarding the share of public spending to allocate to the health sector (30). In higher-income countries, government budget prioritization for health plays a more important role in the public health financing system. Appendix Figure 4 shows that the government health expenditure as a ratio of total government expenditure of higherincome countries is higher than that of less-high-income countries, on average. That is, governments of higherincome countries are willing to give greater priority to health in their limited budgets. Due to this prioritization, government fiscal expansion in health drives a greater increase in public health prepayment over a longer period of time.

Regarding differences between the 2 groups categorized based on public prepayment, we found that in countries with more public-dominated health-financing systems, the public and total health prepayment levels responded more strongly to the shock of government health budgets. Government health budgets made a greater contribution to the variation in the level of public health prepayment in these countries. These results make economic sense. When the share of health prepayment that is channelled from the public sector increases, the policy transmission mechanism is less obstructed and more effective. For instance, it is typical that public health financing dominates in Northern Europe, including Norway and Sweden, which are reputed for their nearly universal health coverage and low OOP payment per capita. It is suggested that financial protection improves as reliance on public prepayment increases.

Another interesting point is that in the less publicdominated group, lower-income countries, such as Mexico and Turkey, tend to have weaker fiscal capacity to finance health prepayments. Thus, government health budgets play a limited role in public health prepayment, leading to weaker financial protection for citizens. However, despite an increase in income levels, government health budgets do not necessarily have a greater impact on public prepayment levels. The extent of financial protection of individuals is closely associated with the proportion of public prepayment. For instance, the public sector is less dominant in the health financing system of the USA, accompanied by the highest OOP payment per capita worldwide, although the US government spends the most on health among the world's top 10 economies.

There are important lessons to be learned from the OECD countries for policy-makers seeking to adjust the role of government expenditure on health; specifically, policy choices should be based on the comparison of impacts on different financing sources (i.e., public and private). Our findings show that the increase in government health expenditure ratio has positive impacts on public and total prepayment levels, but little impact on the level of private prepaid plans. A health system that relies mainly on high levels of government funding and a high share of prepayment sources in overall health spending generally provides better and more equitable access to services and financial protection. Therefore, strengthening government health budgets is essential for increasing public health prepayment, which is a key factor for achieving the Sustainable Development Goal for health. However, government budget prioritization has not been fully tapped in lower-income countries, leaving room for more investments in health (30). Based on the group comparisons, low-income countries require greater attention to prioritizing health in government budgets and better exploiting them to increase health prepayment levels. Additionally, the dynamic relationship between government health budget and the level of 
health prepayment indicates that policy implementations may have delayed effects, which should be considered in policy decision-making.

However, there were several limitations to the present study. Due to data unavailability, the direct and indirect effects of government health budgets on the level of health prepayment could not be distinguished. For example, government expenditure on health can influence the health prepayment through direct transfers to health-financing schemes or indirectly, by improving individuals' incentives to purchase public/private health insurance. There may also have been a methodological limitation since the PVAR model was less theory based compared to traditional structural models, while other factors that may affect health payment levels were not included in the model. We leave such considerations for future research.

\section{Conclusion}

This study shows that government health budgets have a long-term equilibrium relationship with and play a significant role in explaining the fluctuations in the level of public and total prepayment. By contrast, government health expenditure does not systematically crowd out private prepaid plans and contributes little to explaining their variations.

Funding: None.

Competing interests: None declared.

\section{Impact du budget de l'État sur les niveaux de prépaiement pour les soins de santé : données probantes des pays membres de l'OCDE}

\section{Résumé}

Contexte : Le prépaiement pour les soins de santé, un indicateur clé du cadre de suivi des objectifs de développement durable, est fortement associé à la protection financière des ménages ; toutefois, l'impact du budget public de la santé sur le niveau de prépaiement a rarement été examiné.

Objectifs : Répondre aux questions de recherche suivantes. 1) Une augmentation du budget public de la santé se traduitelle par des taux de prépaiement plus élevés dans le système de financement des soins de santé ? 2) Quels sont les effets du budget public de la santé sur le prépaiement public et les systèmes privés de prépaiement ? 3) Quelles sont les hétérogénéités entre les groupes de pays ayant des niveaux de revenu et des systèmes de prépaiement de santé différents?

Méthodes: Pour la période 1995-2016, 34 membres de l'Organisation de coopération et de développement économiques $(\mathrm{OCDE})$ ont procédé à une analyse de la co-intégration des panels, de la fonction de réponse impulsive et de la décomposition des variances.

Résultats : Le budget public de la santé est depuis longtemps en équilibre avec le niveau des prépaiements publics et totaux. Cependant, une relation stable n'a pas pu être confirmée avec les systèmes privés de prépaiement. En outre, le budget de la santé a joué un rôle positif important en expliquant les fluctuations de l'ensemble des prépaiements et des prépaiements publics sur une longue période, c'est-à-dire 51 et 37 périodes, respectivement. Compte tenu des différences entre groupes de pays, les impacts sont plus importants pour ceux dont les niveaux de revenu sont plus élevés et dont les systèmes de financement de la santé sont plus à dominante publique.

Conclusions : Le budget public de la santé est lié depuis longtemps aux niveaux du total des dépenses prépayées et des prépaiements publics. En revanche, il ne permet pas de supplanter systématiquement les systèmes privés de prépaiement.

$$
\begin{aligned}
& \text { أثر الميز انية الحكومية على مستويات الدفع المسبق في مجال الصحة: دلائل مستمدة من بلدان منظمة التعاون و التنمية في الميدان الاقتصادي } \\
& \text { ينج تشانج، جاك فانيست، وينكينج بان، ليوي تشانج } \\
& \text { الخالاصة } \\
& \text { الخلفية: يرتبط الدفع المسبق للحصول على الخدمات الصحية، وهو مؤشر رئيسي في إطار رصد أهداف التنمية المستدامة، بصورة وثيقة بالحماية المالية }
\end{aligned}
$$

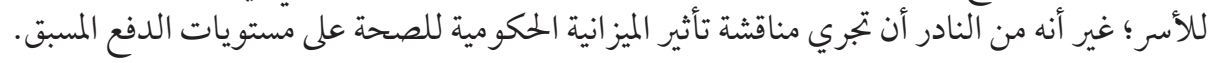

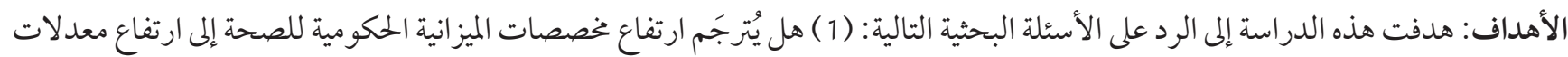

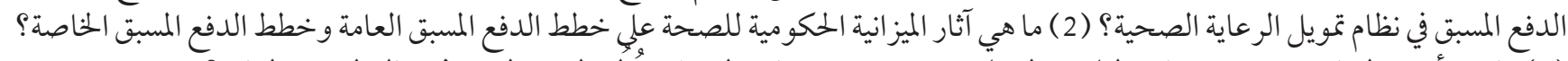

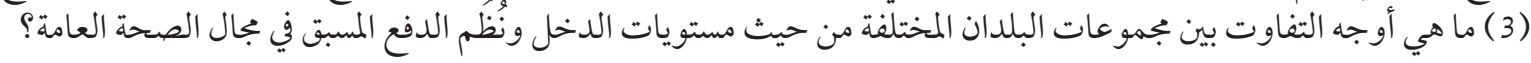

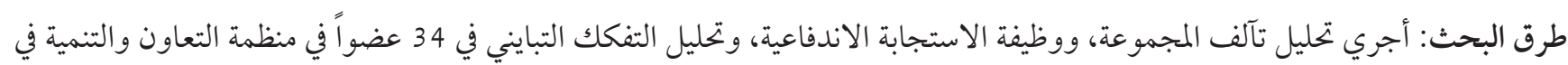

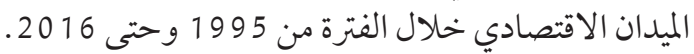




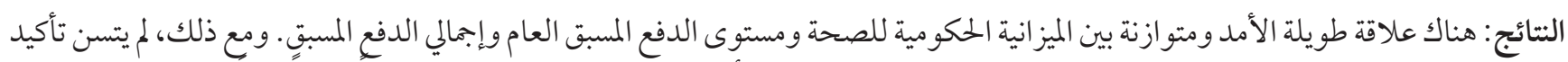

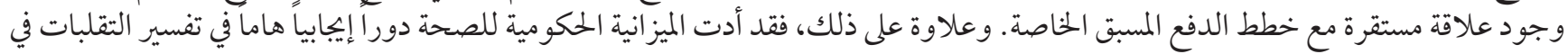

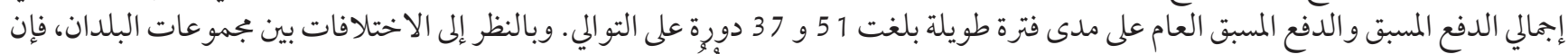

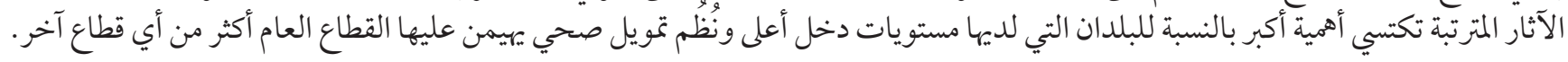

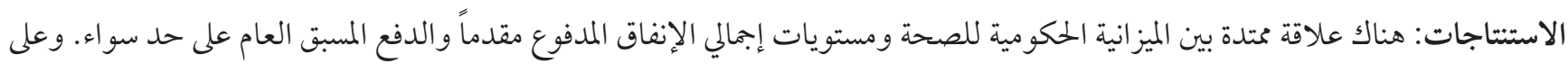

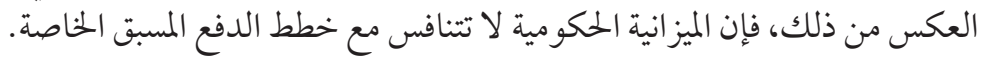

\section{References}

1. New perspectives on global health spending for universal health coverage. Geneva: World Health Organization; 2018 (https:// www.who.int/health_financing/topics/resource-tracking/new-perspectives/en/, accessed 10 August 2020).

2. Carrin G, Zeramdini R, Musgrove P, Pouiller JP, Valentine N, Xu K. Impact of risk sharing on the attainment of health system goals. In: Preker A and Carrin G, editors. Health financing for poor people: resource mobilization and risk sharing. Washington, DC: World Bank; 2004:397-416.

3. Easterly W, Levine R. Africa's growth tragedy: policies and ethnic divisions. Q J Econ. 1997 Nov;112(4):1203-50. https://doi. org/10.1162/003355300555466

4. Flora P, Alber J. Modernization, democratization and the development of welfare states in western Europe. In: Flora P and Heidenheimer AJ, editors. The development of welfare states in Europe and America. New Brunswick and London: Transaction Books; 1981:37-80. https://doi.org/10.4324/9781351304924-5

5. Hopkins S, Kidd MP. The determinants of the demand for private health insurance under Medicare. Appl Econ. 1996;28(12):162332. https://doi.org/10.1080/000368496327598

6. Fang K, Shia BC, Ma S. Health insurance coverage, medical expenditure and coping strategy: evidence from Taiwan. BMC Health Services Res. 2012;12(1):58-72. https://doi.org/10.1186/1472-6963-12-442

7. Yamada T, Yamada T, Chen CC, Zeng W. Determinants of health insurance and hospitalization. Cogent Econ Finance. 2014;2(1):920271. https://doi.org/10.1080/23322039.2014.920271

8. 8. Ying XH, Hu TW, Ren J, Chen W, Xu K, Huang JH. Demand for private health insurance in Chinese urban areas. Health Econ. 2007 Oct;16(10):1041-50. https://doi.org/10.1002/hec.1206

9. Stavrunova O, Yerokhin O. Tax incentives and the demand for private health insurance. J Health Econ. 2014 Mar;34:121-30. https://doi.org/10.1016/j.jhealeco.2014.01.001

10. Liu TC, Chen CS. An analysis of private health insurance purchasing decisions with national health insurance in Taiwan. Soc Sci Med. 2002 Sep;55(5):755-74. https://doi.org/10.1016/S0277-9536(01)00201-5

11. Bourne PA, Kerr-Campbell MD. Determinants of self-rated private health insurance coverage in Jamaica. Health. 2010 Jun;2(6):541-50. https://doi.org/10.4236/health.2010.26081

12. Kiil A. Determinants of employment-based private health insurance coverage in Denmark. Nordic J Health Econ. 2011;1(1):29-60. https://doi.org/10.5617/njhe.194

13. Besley T, Hall J, Preston I. The demand for private health insurance: do waiting lists matter? J Public Econ. 1999 May;72(2):155-81. https://doi.org/10.1016/S0047-2727(98)00108-X

14. Costa J, Garcia J. Demand for private health insurance: How important is the quality gap? Health Econ. 2003 Jul;12(7):587-99. https://doi.org/10.1002/hec.756 PMID:12825210

15. Cornelis VM, Vincent VPP, Hernandez-Pena P, Piet V. Health expenditure data for policy: Health accounts, national accounts or both? Health Policy 2018 Aug;122(8):885-91. https://doi.org/10.1016/j.healthpol.2018.06.004

16. Zhang Y, Wang R, Yao X. Assessing determinants of health care prepayment in China: Economic growth or government willingness? New evidence from the continuous wavelet analysis. Int J Health Planning Manage. 2019 Jan/Mar;34(1)e694-712. https:// doi.org/10.1002/hpm.2683

17. Dieleman JL, Hanlon M. Measuring the displacement and replacement of government health expenditure. Health Economics 2014 Feb;23(2):129-40. https://doi.org/10.1002/hec.3016 PMID:24327240

18. Liang LL, Mirelman AJ. Why do some countries spend more for health? An assessment of sociopolitical determinants and international aid for government health expenditures. Soc Sci Med. 2014 Aug;114:161-8. https://doi.org/10.1016/j.socscimed.2014.05.044 PMID:24929917

19. Johnston BM, Burke S, Barry S, Normand C, Fhallúin MN, Thomas S. Private health expenditure in Ireland: Assessing the affordability of private financing of health care. Health Policy 2019 Oct;123(10):963-9. https://doi.org/10.1016/j.healthpol.2019.08.002

20. Love I, Zicchino L. Financial development and dynamic investment behavior: evidence from panel vector autoregression. Q Rev Econ Finance. 2006 May;46(2):190-210. https://doi.org/10.1016/j.qref.2005.11.007

21. Arellano M, Bover O. Another look at the instrumental variable estimation of error-components models. J Econ. 1995 Jul;69(1):2951. https://doi.org/10.1016/0304-4076(94)01642-D 
22. Grossmann A, Love I, Orlov AG. The dynamics of exchange rate volatility: a panel var approach. J Int Financial Markets Institutions Money. 2014 Nov;33:1-27. https://doi.org/10.1016/j.intfin.2014.07.008

23. Levin A, Lin CF, Chu C. Unit root tests in panel data: asymptotic and finite sample properties. J Econometrics. 2002 May;108(1):124. https://doi.org/10.1016/S0304-4076(01)00098-7

24. Breitung J. The local power of some unit root tests for panel data. Adv Econometrics. 2000;15:161-77. https://doi.org/10.1016/So7319053(00)15006-6

25. Im KS, Pesaran MH, Shin Y. Testing for unit roots in heterogeneous panels. J Econometrics. 2003 Jul;115(1):53-74. https://doi. org/10.1016/S0304-4076(03)00092-7

26. Maddala GS, Wu S. A comparative study of unit root tests with panel data and a new simple test. Oxford Bull Econ Stat. 1999 Nov;61(S1):631-52. https://doi.org/10.1111/1468-0084.0610s1631

27. Choi I. Unit root tests for panel data. J Int Money Finance. 2001 Apr;20(2):249-72. https://doi.org/10.1016/S0261-5606(00)00048-6

28. Pedroni P. Critical values for cointegration tests in heterogeneous panels with multiple regressors. Oxford Bull Econ Stat. 1999 Nov;61(S1)653-70. https://doi.org/10.1111/1468-0084.0610s1653

29. Kao C. Spurious regression and residual-based tests for cointegration in panel data. J Econometrics. 1999 May;90(1)1-44. https:// doi.org/10.1016/S0304-4076(98)00023-2

30. Public spending on health: a closer look at global trends. Geneva: World Health Organization; 2018 (https://apps.who.int/iris/bitstream/handle/10665/276728/WHO-HIS-HGF-HF-WorkingPaper-18.3-eng.pdf?ua=1, accessed 11 August 2020).

31. Dong H, Mugisha F, Gbangou A, Kouyate B, Sauerborn R. The feasibility of community-based health insurance in Burkina Faso. Health Policy. 2004 Jul;69(1):45-53. https://doi.org/10.1016/j.healthpol.2003.12.001

32. Shafie AA, Hassali MA. Willingness to pay for voluntary community-based health insurance: Findings from an exploratory study in the state of Penang, Malaysia. Soc Sci Med. 2013 Nov;96:272-6. https://doi.org/10.1016/j.socscimed.2013.02.045 PMID:23528670

33. Bock J-O, Matschinger H, Brenner H, Wild B, Haefeli WE, Quinzler R, et al. Inequalities in out-of-pocket payments for healthcare services among elderly Germans results of a population-based cross-sectional study. Int J Equity Health. 2014 Jan 8;13:3. https:// doi.org/10.1186/1475-9276-13-3 PMID:24397544

34. Binam JN, Nkama A, Nkendah R. Estimating the willingness to pay for community health prepayment schemes in rural areas: a case of the use of contingent valuation surveys in centre Cameroon (http://citeseerx.ist.psu.edu/viewdoc/download?doi=10.1.1.595.9298\&rep=rep1\&type=pdf, accessed 11 August 2020).

35. Onwujekwe O, Okereke E, Onoka C, Uzochukwu B, Kirigia J, Petu A. Willingness to pay for community-based health insurance in Nigeria: do economic status and place of residence matter? Health Policy Planning. 2010 Mar;25(2):155-61. https://doi.org/10.1093/ heapol/czpo46 PMID:20156920

36. Khan JA, Ahmed S. Impact of educational intervention on willingness-to-pay for health insurance: A study of informal sector workers in urban Bangladesh. Health Econ Rev. 2013 Apr 29;3(1):12. https://doi.org/10.1186/2191-1991-3-12 PMID:23628206

37. Alesina A, Tabellini G. A positive theory of fiscal deficits and government debt. Rev Econ Stud. 1990 Jul;57(3):430-14. https://doi. $\operatorname{org} / 10.2307 / 2298021$

38. Miron JA, Weil DN. The genesis and evolution of social security. In: Bordo MD, Goldin C, White EN, editors. The defining moment: the great depression in the American economy in the twentieth century. Chicago: University of Chicago Press; 1998:297322.

39. Becker GS, Mulligan CB. Deadweight costs and the size of government. J Law Econ. 2003 Oct;46(2):293-340. https://doi. org/10.1086/377114

40. Carrin G, James C. Social health insurance: key factors affecting the transition towards universal coverage. Int Soc Security Rev. 2005 Jan;58(1):45-64. https://doi.org/10.1111/j.1468-246X.2005.00209.x

41. Lim JH, Kim SG, Lee EM, Bae SY, Park JH, Choi KS, et al. The determinants of purchasing private health insurance in Korean cancer patients. J Prev Med Public Health 2007 Mar;40(2):150-154. https://doi.org/10.3961/jpmph.2007.40.2.150 PMID:17426427 